\title{
Erythema ab igne
}

\section{Erythema ab igne}

\section{GYÖNGYÖSSY ORSOLYA DR., DARÓCZY JUDIT DR.}

\author{
Egyesített Szent István és Szent László Kórház - Rendelôintézet, \\ Bốrgyógyászati Szakrendelő és Lymphoedema Rehabilitációs osztály, Budapest
}

\section{ÖSSZEFOGLALÁS}

Az erythema ab igne jelentése „börpír a tüztől”. A börtünetek az ismétlődő, 43-47 C fokos höhatásra alakulnak ki. Régebben kályha, sugárzó hố okozta a tüneteket, újabban laptop, ágymelegítő hatása is bizonyított. A klinikai tüneteket retikuláris pigmentáció, petechiák, hólyagok, atypikus sebek jellemzik. Három észlelt esetben lehetôség volt az eltérő klinikai megjelenés bemutatására. A bőr mikrocirkulációs zavara lézer-Doppler módszerrel igazolható. A szerzôk elsóként vetikfel, hogy a börtünet kialakulása a bör kapillárisainak a hóhatásra adott kóros reakciójával függhet össze. A ritkán diagnosztizált kórkép felismerése azért fontos, mert az ismétlödő vagy folyamatos hám irritáció következtében elszarusodó laphámrák keletkezhet és Merkel sejtes carcinomát is leírtak. A kiváltó ok felismerése és kiküszöbölése elözheti meg a recidivát és a hám irritáció következtében keletkező malignus tumor kialakulását.

\section{Kulcsszavak: \\ Erythema ab igne - krónikus hớhatás - reticularis hyperpigmentáció - kóros mikrocirculáció - laphám carcinoma}

\section{SUMMARY}

Erythema ab igne means ,redness from fire”. Symptoms resulting from prolonged or repeated exposure to moderate heat. The heat source used to be stove, and other infrared radiation, nowadays the role of laptop computer, hot blanket and many others are proved. The clinical symptomes are reticular hyperpigmentation, petechia, blisters, aypical ulcers. Three different cases show the variant clinical manifestation. Pathologic dermal microcirculation was verified with Laser Doppler examination. The authors first raised the relationship between abnormal capillary respond to heat and the onset of skin symptoms. It is important to be familiar with this rarely diagnosed disease because the chronic epidermal irritation may leads to squamous cell, and rarely Merkel cell carcinoma development. Realise and avoid the heat source can prevent progression and malignant transformation.

\section{Key words: \\ Erythema ab igne - heat exposure - reticular hyperpigmentation - pathologic dermal microcirculation - squamosus cell carcinoma}

Az ,erythema e calore” vagy “erythema ab igne” (EAI) jelentése „,bőrpír a tűztől”, az elnevezés a betegség kiváltó okát határozza meg. A tüneteket elhúzódó, folyamatosan ismétlődő 43-47 Celsius fok közötti, égést nem okozó, közvetlen hôhatás okozza. Kályhák, nyitott tûzterû kandallók, iparban vagy sütödékben használatos hôkemencék szerepelnek kiváltó okként. Foglalkozásukból adódóan pékek, öntőmunkások karján számoltak be erythema ab igne kialakulásáról. A központi fútés bevezetésével a kórkép előfordulása világszerte csökkent, azonban az elmúlt tíz évben, hazánkban (is) ismét nagy népszerúségre tettek szert a kandallók és cserépkályhák, illetve rosszabb szociális körülmények között élőknél, a szén- és fatüzelésú kályhák, ezért a kórkép előfordulásával nagyobb számban ismételten számolni kell.
A klinikai kép jellemzője: körülírt területen, elsôsorban a combon és a lábszáron reticularis rajzolatú erythema, kávébarna hyperpigmentatio, teleangiectasiák. A hólyagok megjelenése és a nehezen gyógyuló sebek ritkák, az évek óta fennálló tünetek esetén hámatrophia látható. Nőknél és idősebbeknél gyakoribb. A károsító hőhatás elhagyása esetén a tünetek javulnak, vagy megszúnnek. Fontos tehát a kóroki háttér tisztázása, a részletes anamnézis felvétel.

A tünetek kialakulásának oka nem tisztázott. A szövettani vizsgálat a dermalis erek tágulatát, mérsékelt ér körüli gyulladást mutat. A reticularis pigmentáció a bőrerek lefutását követi, ezért felmerül a bőr kapillárisok károsodása és javasolt a bőrerek funkcionális vizsgálata.

Levelező szerzô: Dr. Gyöngyössy Orsolya, Egyesített Szent István és Szent László Kórház - Rendelôintézet, Bőrgyógyászati Szakrendelő és Lymphoedema Rehabilitációs osztály, Budapest, Magyarország•e-mail: gyongyossy.orsolya@gmail.com 


\section{Eset és módszer}

3 beteg esete kerül ismertetésre. A lézer-Doppler (LD) vizsgálat alkalmas a bőr hőhatásra kialakult mikrocirkulációs zavarának a vizsgálatára. A lézer-Doppler vizsgálat a Doppler elven alapszik. A lézer fény a kapillárisokban mozgó vörösvérsejtekről visszaverődik, amit a múszer detektora érzékel. A fényhullám frekvenciájának a változása arányos a mozgó vörösvérsejtek számával. A készülék (Laser-Doppler PeriFlux System 5000 (Perimed, Stockholm, Sweden) a frekvencia változásával arányosan kiszámítja a hám alatti kb. $1,5 \mathrm{~mm}^{3}$ területen a bôrkapillárisokban történố véráramlást. A perfúzió vizsgálatára szolgáló különböző provokációs tesztek (VAR- venoarterialis reflex, RH- reaktiv hyperaemia teszt, TSR - termo stimulációs reakció) közül a lokális melegítés (egy perces, $44^{\circ} \mathrm{C}$ ) hatását vizsgáltuk.

\section{Esetismertetés}

1. eset. 83 éves nô anamnézisében stabil esszenciális hypertonia, obesitas, adnexectomia szerepelt. Ödémamentesítő kezelésre ún. „vastag láb” diagnózissal került. A primér varicositás, krónikus vénás elégtelenség következtében kialakult flebödéma az alsó végtagokon lipödémával társult. A lipödéma gyakori tünet, kóros szerkezetû, kóros eloszlású zsírszövet, amely elsôsorban a combon és a felkaron jelenik meg, ezáltal a testalkat deformálódásához vezet. Az ödémaképződés hátterében kombinált metabolikus szindróma (cukor-, és zsíranyagcsere) és mikrocirkulációs zavar feltételezhetô. A beteg évek óta észlelt a combok feszítô felszínén, illetve az alhason ágazatos pigmentációt, amely panaszt nem okozott. Időnként apró felületes sebeket is észlelt a rajzolatban. Rákérdezésre elmondta, hogy fémöntödében dolgozott.

Klinikai kép: Vizsgálatakor lipödéma típusos képe mellett (ödémas zsírpárnák, matracbőr) a combok feszítő felszínén, illetve az alhason, szimmetrikus eloszlásban hyperpigmentált reticularis rajzolat volt látható, helyenként 3-5mm-es atrophiás területekkel (1. ábra).

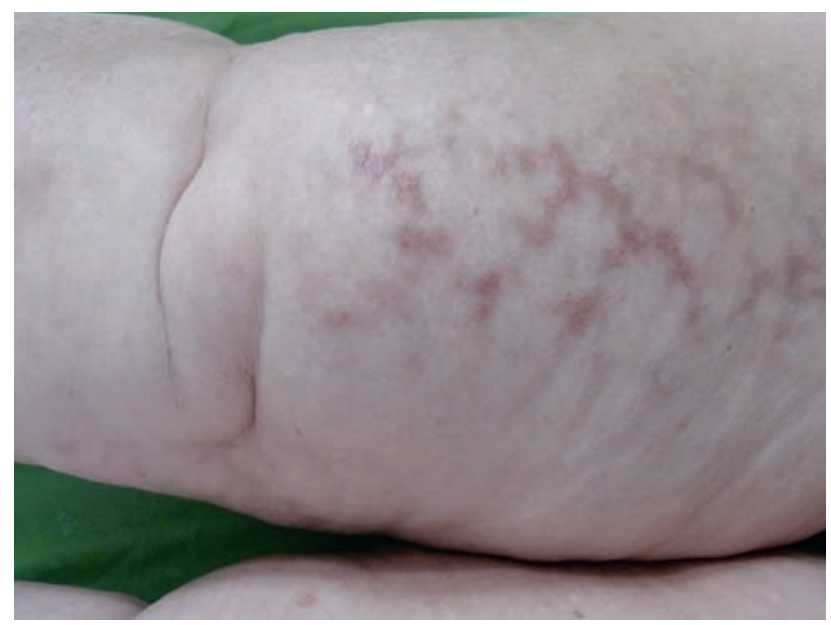

1. ábra

Lipödémás alkat, matracbőr. A combok feszítő felszínén jól látható a barna hálózatos rajzolat, helyenként pontszerú atrophia

A beteg komplex ödémamentesítő kezelése során (rövid megnyúlású rugalmas pólya, torna) a comb és a has területén 3-10mm nagyságú, szalmasárga bennékû vesiculák, hólyagfedél lesodródása után felületes erosiok keletkeztek. A szomszédos bőrterületen bíborvörös purpurák voltak (2. ábra). Hólyagmegnyitás, helyi antiszeptikus ecsetelők alkalmazása után a felületes sebek gyorsan hámosodtak.

Vizsgálatok: szövettani vizsgálat az ép hólyagból történt és subepidermalis hólyagképződést igazolt. A hólyagot körülvevő bőrterületbôl végzett direkt immunfluoreszcens vizsgálat negatív volt.

Laboratóriumi leletekben a csökkent thrombocyta számon (105 G/l) kívül érdemi eltérés nem volt. A bôrvérzések hátterében elsôsorban a lipödemához társuló kapilláris vérerek szakadékonysága és a társuló thrombocytopenia vezethetett.

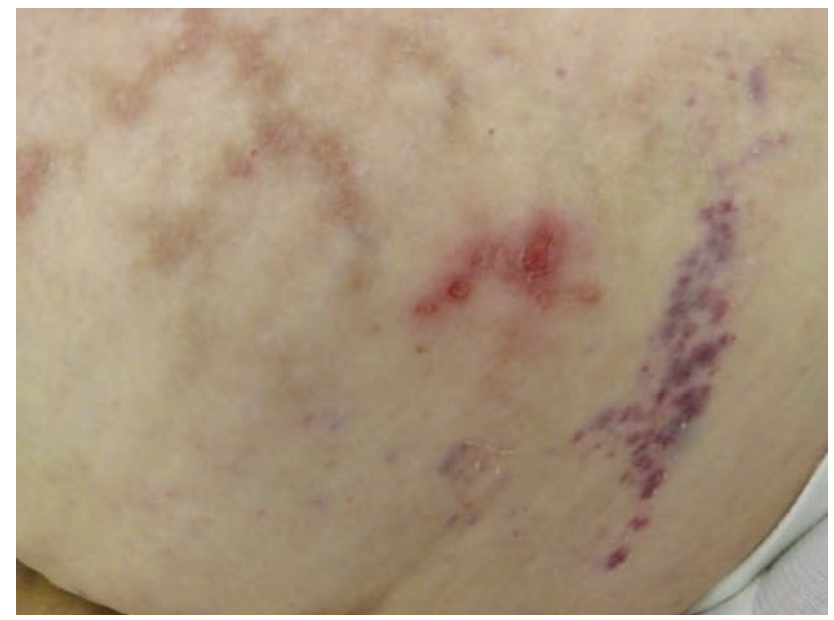

2. ábra

Nagyobb nagyítású képen a pigmentált rajzolatnak megfelelően 3-10 mm-es erosiok, gyulladt környezetben.

A lipödéma komplex kezelése során alkalmazott rövid megnyúlású pólya szélénél kialakult suffusio a kis erek szakadékonyságára utal

2. eset: 62 éves nőbeteg anamnézisében említésre méltó megbetegedés nem szerepel. A beteg krónikus vénás elégtelenség és lipödéma komplex ödémamentesítő fizioterápiás kezelése céljából került osztályos felvételre.

Felvételkor az alsó végtagokon II. stádiumú lipödéma és felületes vénás rajzolat volt látható, amit a tibia felett ujjbenyomatot tartó ödéma kísért. Mindkét comb hajlító felszínén, és a poplitealis régió felett hálózatos rajzolatú, barna színú bőrtünet volt. Rákérdezésre elmondta, hogy a combon, lábszáron lévő seprúvénákat kozmetikus kezelte lézerrel (a kezelésrôl pontos adatok nem álltak rendelkezésre). A kezelés után néhány héttel vette észre, hogy a beavatkozás területén barna színú bőrelváltozás keletkezett. A tünet panaszt nem okozott.

Klinikai kép: Mindkét comb hajlító felszínén, az alsó harmadban, combközépig terjedően barnás-vörös reticularis rajzolat volt látható. A bal poplitealis régió lateralis részén hypopigmentált vonalas heg, és 2-3 mm nagyságú, hypopigmentált kerek atrophiás területek és hegek a tágult vénás hálózatnak megfelelően (3. ábra).

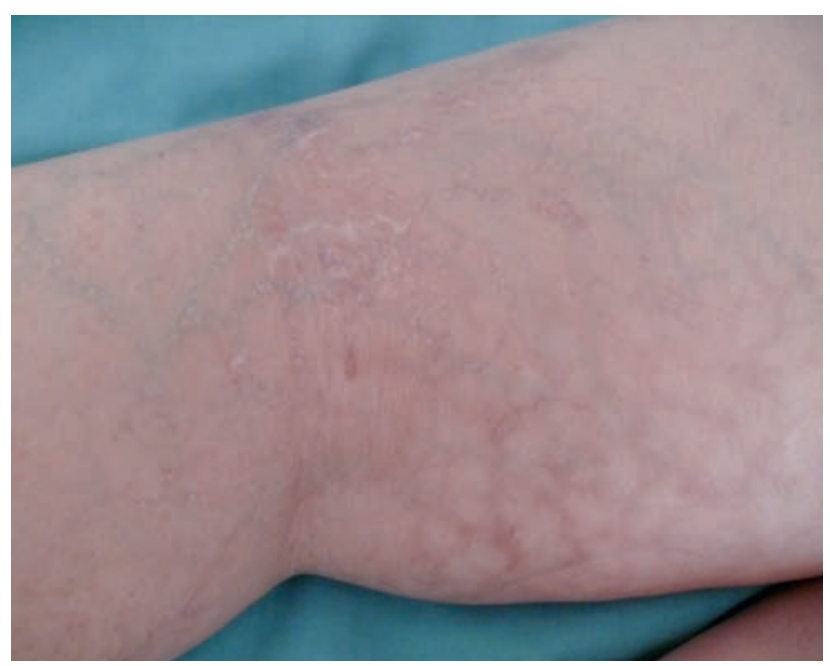

3. ábra

A poplitealis régióban láthatóak a lézeres varicectomia depigmentált kerek hegei és az erythema $\mathrm{ab}$ igne pigmentált bőrtünetei 


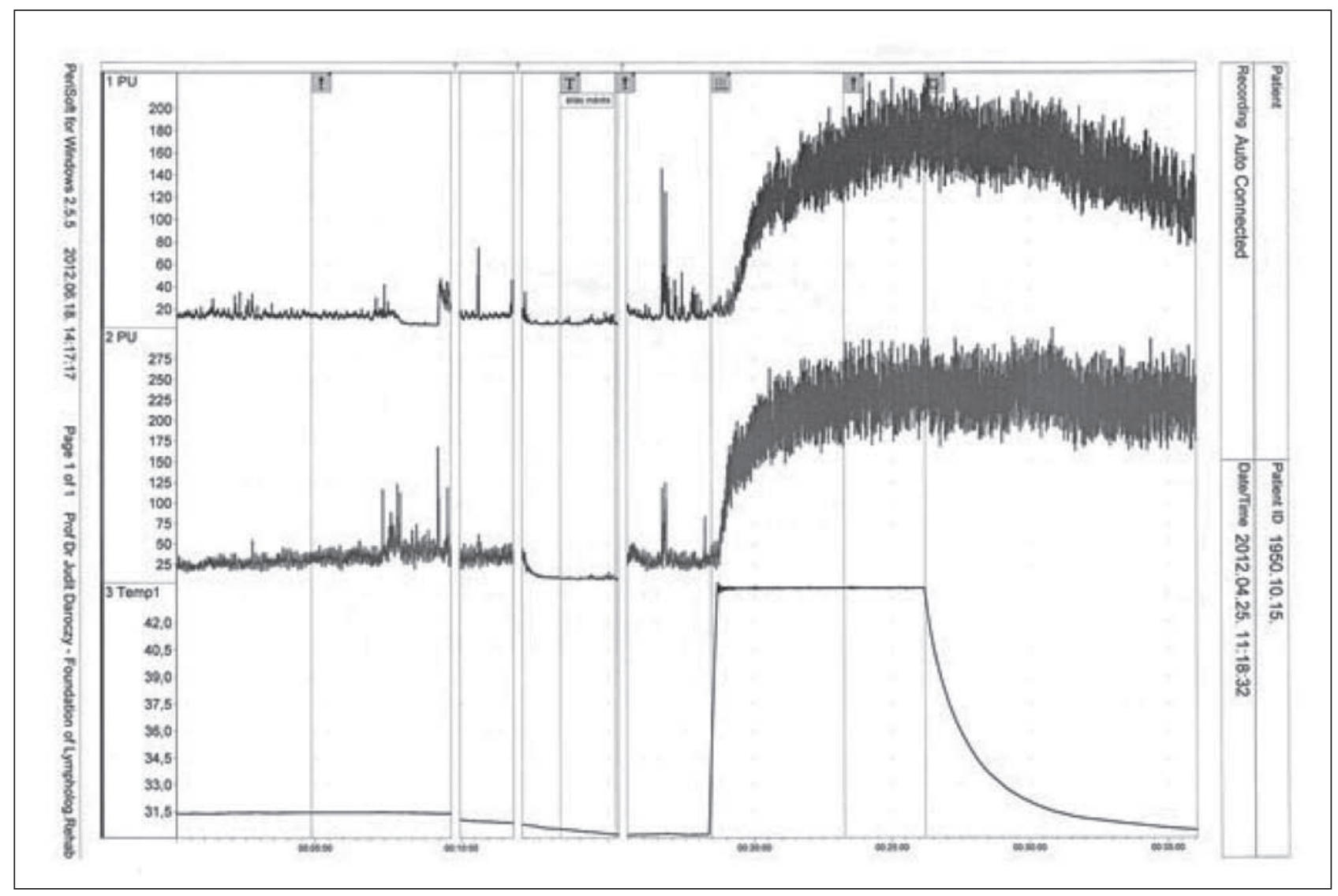

4. ábra

A lézer Doppler vizsgálat kóros hőregulációt igazolt. A hőhatásra kialakult vazodilatáció kórosan elhúzódik, a megemelkedett görbe nem tér vissza a kiindulási pontra

Vizsgálatok: Lézer-Doppler vizsgálattal funkcionális mikrocirkulációs eltérést, ezen belül kóros termoregulációt mutattunk ki 44. ábra).

3. eset: 75 éves nőbeteg anamnézisében kezelt, esszenciális hypertonia szerepel. Ambulanciánkat a lábszáron észlelt vöröses-barna rajzolat miatt kereste fel. A tüneteket más szubjektív panasz nem kísérte.

Klinikai kép: Mindkét alsó végtagon, elsősorban a feszítő felszínen, a térdek körül, a tibia felett, enyhén erythemas, ill. a barna színú pigmentáció különböző árnyalatait mutató hálózatos rajzolat volt (5. ábra).

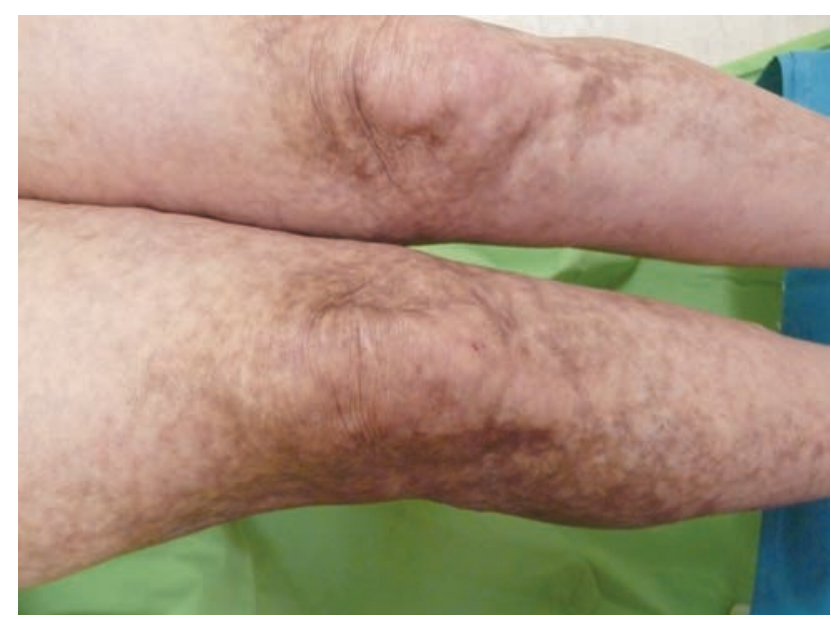

5. ábra

Mindkét alsó végtagon, elsősorban a térdek körül megfigyelhető barna, retikuláris rajzolat
Többszörös beszélgetés során megállapítható volt, hogy a beteg a tünetek megjelenését megelőzően rendszeresen kályhát használt közvetlen melegedésre. A beteget tájékoztattuk, hogy mi okozta a bőr elszíneződését, és tanáccsal láttuk el, hogyan kerülheti el a tünetek további súlyosbodását. Kontroll vizsgálatokon az erythema megszűnését, a hyperpigmentált rajzolat halványodását észleltük.

\section{Megbeszélés}

Az EAI krónikus, ismétlődő, égést nem okozó hőhatásra kialakuló reticularis, teleangiectasiákkal, hám atrophiával kísért hyperpigmentált dermatosis. Kialakításában leggyakoribb a sugárzó hő (kályha, kemence) de számos más hőforrás szerepét leírták: melegvizes palack (1), elektromos melegítésû́ takarók (2), hősugárzó, ülésfútés, pl. autóban (3), laptop computer, amelyet elsôsorban serdülők, fiatal felnőttek rendszeresen a combjukra támasztva használnak (4), gyógynövények felhasználásával készült forró lábfürdők (5). A lézeres varicectomia etiológiai szerepe az EAI kialakulásában eddig nem került leírásra. A lézeres technológia alapja az erekben termális hatásra létrejövő endothelsérülés és coagulatio, adott körülmények között oki szerepe nem kizárható. A második bemutatott esetünkben azért a lézeres kezelés hatása is felvethetô.

Az EAI korai stádiumában észlelt erythema hátterében szövettani vizsgálattal vazodilatáció, mérsékelt superficialis, perivascularis lymphocytas infiltratum ész- 
lelhető. A később kialakuló hyperpigmentált rajzolat szövettani háttere pigmentrögök - melanophagok megjelenése a felső dermisben. A szövettani vizsgálatok eredménye hőkárosodásra utal, amely megfelel a krónikus napfénykárosodásban észlelt elváltozásoknak: hám atrophia, phagocytált pigment rögök a dermisben, összetöredezett, megvastagodott kollagén kötegek és a IV típusú kollagén mennyiség csökkenése vagy eltûnése (4). A hólyagos forma kialakulásában a lamina basalis felépítésében résztvevő IV típusú kollagén degenerációja, ill. a lamina densát a dermis kollagén rostjaihoz kapcsoló, un. anchor rostok sérülése játszhat szerepet. Bullosus formában észlelt esetünkben subepidermalis hólyagképzôdés volt, ami a basalis lamina területén kialakult szöveti degenerációra utal. Immunfluoreszcens vizsgálat kóros immundepozitumot nem azonosított a hólyag körüli területből vett mintában, ami megegyezik az irodalmi adatokkal (6).

A ritka bullosus EAI variáns esetében a kialakuló erosiokból atípusos, lassan gyógyuló felületes fekélyek keletkeznek. A bullaképződés hátterében a krónikus hôhatás szerepének tisztázása fontos, mert ellenkező esetben a seb progressziója valószínú. A hőexpozíció megszüntetése esetén a sebek néhány nap/hét alatt hypo-, vagy hyperpigmentált hegek hátrahagyásával gyógyulnak.

Differenciál diagnózisként a klinikai kép alapján felmerül: poikiloderma, livedo reticularis (7), livedo vasculitis, cutis marmorata, bullosus lichen ruber planus, lokalizált bullosus pemphigoid. A klinikai kép, részletes anamnézissel, esetleg szövettani vizsgálattal kiegészítve, elégséges a helyes diagnózishoz.

A kórkép pontos patogenezise nem ismert. A vazodilatáció a dermis felsố harmadában mind a klinikai (teleangiectasia), mind a szövettani képet jellemzi. Feltételezésünk szerint a dermalis kapillárisok tágulata a bőr mikrocirkulációs zavarára utal és feltételezhetô, hogy a kóros hőreguláció hajlamosíthat a kórkép kialakulására.

A hôreguláció eltéréseinek kimutatása lézer-Doppler (LD) vizsgálattal lehetséges. A módszer adatait sok tényezô befolyásolhatja, pl. a hám vastagsága, a pigmentáció, a kötôszöveti rostok, az interfibrilláris kötőszöveti mátrix, stb. A múszer nem abszolút értékben fejezi ki az adott szöveti áramlást, hanem relatív mérôszámot ad meg. A bőr mikrocirkulációja a hôregulációban igen jelentős szerepet tölt be, a felszínnel párhuzamosan, kb.12 mm mélységben futó termoregulátor kapillárisok és söntök 80-85\%-a a szervezet hóháztartását látja el (8). Normál esetben a melegítés (egy percig, $44{ }^{\circ} \mathrm{C}$ ) hatására a kapillárisok kitágulnak, és az áramlás fokozódik. Adott bőrterületen a melegítés hatására a kapillárisokban LDel kimutatható vazodilatáció, fokozott áramlás alakul ki, mely a hőhatás megszúnése után normál esetben gyorsan, 20-30 másodperc alatt megszúnik, visszatér a normál értónus.

Kóros hőreguláció esetén a melegítés hatására elhúzódó, kóros értágulat állandósul, 5-8 percig nem tér vissza a kiindulási áramlási görbe (4. ábra). Az értágulat a krónikus hőhatás mellett állandósul, kialakul a folyama- tos bőrpír, majd krónikus esetben a teleangiectasia, és az érfal károsodása esetén a szövetbe jutott vörösvérsejtek lebomlása következtében a hemosiderin pigmentáció, amely az EAI klinikai megjelenését elsősorban jellemzi.

A LD vizsgálat funkcionális eltérést mutat, ami magyarázhatja az erek falában és a környezetben is kialakult strukturális változásokat, így a kötőszöveti rostok degenerációját, a hám megvastagodását. A bőr termoregulációért felelős kapillárisainak a kóros múködésére lehet következtetni a LD eredményéból. Annak megítélése, hogy EAI esetében a bőr mikrocirkulációs rendszerének eltérései egyértelmúen kóroki szerepet játszanak, más mikrocirkulációs vizsgáló eljárások is szükségesek, pl. transcután oxigén-nyomásmérés, haemorrheologiai vizsgálatok.

Hasonlóan kóros termoregulációs funkció mérhető krónikus vénás elégtelenségben, diabetes mellitushoz társuló neuropathia esetében és lipödémában is (9).

Mindhárom bemutatott esetekben észleltünk I-II stádiumú lipödémát. A lipödéma olyan krónikus és általában progrediáló állapot, amely a végtagok szimmetrikus megvastagodásával jár. A szövetszaporulatot a subcutan zsírszövet kóros mennyiségú lerakódása okozza és ödéma kialakulásával társul. A zsírszövet endokrinologiai szerepe kiemelkedő és elterjedt kutatások tárgya. A zsírszövetben talált adipokinek olyan molekulák, melyeknek endokrinologiai (cukor-, és zsíranyagcsere) és angiologiai hatásuk is van, így a mikrocirkulációs zavarok kialakulásában az autonóm idegrendszeri károsodás mellett szerepet játszanak (10). További vizsgálatokra van szükség ahhoz, hogy megállapítást nyerjen, hogy az EAI kórkép kialakulására a lipödémás betegek hajlamosak. Ez különösen fontos kérdés annak tükrében, hogy a lipödéma gyakori és ritkán diagnosztizált kórkép.

Az elváltozás daganatmegelőző állapotnak is tekinthetô. Hosszú fennállás, ismételt hőártalom után, az elhúzódó napfény ártalomhoz hasonlóan, keratosis, elszarusodó laphámrák $(11,12,13,14)$ keletkezhet. A ritka Merkel sejtes carcinomát is leírták (15). Említésre méltó, hogy néhány országban a hôkárosodott bőrön kialakult laphámdaganat annak az edénynek a nevét kapta, amely egyéni melegedésre szolgál, és a daganat kialakulásában játszott szerepére utal. A fonott kosárba helyezett, forró szénnel töltött agyag edényt a két comb közé helyezve melegednek és az évekig tartó hőexpozíció az, ami a combok belsô felszínén, illetve alhason egyeseknél laphám carcinoma kialakulását okozza. Kínában - Kang carcinoma, Indiában - Kangri carcinoma, Japánban - Kairo carcinoma a neve $(16,17)$.

Az EAI -nak nincs egyértelmúen bizonyított hatékony kezelése. A legeredményesebb a hőforrás tisztázása és használatának azonnali felfüggesztése. Lokális retinoid készítményekkel és lézerkezeléssel történtek próbálkozások, elsôsorban a kozmetikai panaszokat jelentő tünetek enyhítésére (18).

A hatékony kezelés hiányában fontos a kórkép felismerése, a gondos anamnézis felvétel. 
A kiváltó ok ismeretében annak megszüntetése és a beteg gondos tájékoztatása, utasításokkal történő ellátása megelőzi a súlyos szövődményeket.

\section{IRODALOM}

1. Ashby M.: Erythema ab igne in cancer patients. J R Soc Med. (1985) 78(11), 925-7.

2. Dellavalle R. P., Gillum P.: Erythema ab igne following heating/cooling blanket use in the intensive care unit. Cutis. (2000) 66(2), 136-8

3. Helm T. N., Spigel G. T., Helm K. F.: Erythema ab igne caused by a car heater. Cutis. (1997) 59(2), 81-2.

4. Giraldi S., Diettrich F., Abbage K. T., mtsai.: Erythema ab igne induced by a laptop computer in an adolescent. An. Bras. Dermatol. (2011) 86(1), 128-30.

5. Chen J. F., Liu Y. C., Chen Y. F., mtsai: Ab igne after footbath with Chinese herbal remedies. J Chin Med Assoc. (2011) 74(1), 51-3.

6. Kokturk A., Kaya T. I., Baz K., mtsai.: Ikizoglu G. Bullous erythema ab igne Dermatology Online Journal (2003) 9(3), 18.

7. Riahi R. R., Cohen P. R., Robinson F. W., mtsai.: Erythema ab igne mimicking livedo reticularis. Int J Dermatol. (2010) 49(11), 1314-7.

8. Farkas K.: Lézer-Doppler- áramlásmérés. LAM. (1998) 8, 4-12.

9. Daróczy J.: Laser Doppler vizsgálatok az alsó végtag keringésvizsgálatában. Orv. Hetil. (2003) 25, 125-134.
10. Wenczl E., Daróczy J.: A lipödéma, egy alig ismert kórkép: diagnózis, társbetegségek, kezelés. Orv. Hetil. (2008) 149, 2121-7.

11. Arrington J. H. 3rd, Lockman D. S.: Thermal keratoses and squamous cell carcinoma in situ associated with erythema ab igne. Arch Dermatol. (1979) 115(10), 1226-8.

12. Miller K., Hunt R., Chu J., mtsai.: Erythema ab igne. Dermatol Online J. (2011) 17(10), 28.

13. Rudolph C. M., Soyer H. P., Wolf P., mtsai.: Squamous epithelial carcinoma in erythema ab igne. Hautarzt. (2000) 51(4), 260-3.

14. Akasaka T., Kon S.: Two cases of squamous cell carcinoma arising from erythema ab igne Nihon Hifuka Gakkai Zasshi. (1989) 99(6), 735-42.

15. Jones C. S., Tyring S. K., Lee P. C., mtsai.: Development of neuroendocrine (Merkel cell) carcinoma mixed with squamous cell carcinoma in erythema ab igne. Arch Dermatol. (1988) 124(1), 110-3.

16. Wani I.: Kangri cancer. Surgery. (2010) 147(4), 586-8.

17. Teli M. A., Khan N. A., Darzi M. A., mtsai.: Recurrence pattern in squamous cell carcinoma of skin of lower extremities and abdominal wall (Kangri cancer) in Kashmir valley of Indian subcontinent: impact of various treatment modalities. Indian J Dermatol. (2009) 54(4), 342-6.

18. Cho S., Jung J. Y., Lee J. H.: Erythema ab igne successfully treated using 1,064-nm Q-switched neodymium-doped yttrium aluminum garnet laser with low fluence. Dermatol Surg. (2011) 37(4), 551-3.

Érkezett: 2013. 04. 25.

Közlésre elfogadva: 2013. 06. 10.

\section{Hazai hírek}

A Bőrgyógyászati és Venerológiai Szemle Szerkesztőbizottsága a lap 2012. évi Nívódíját az alábbi közleményeknek ítélte:

\section{Legjobb összefoglaló munka}

Mócsai Gábor, Markó Lóránt dr., Remenyik Éva dr., Szegedi Andrea dr.: A bőr barrier felépítése, különös tekintettel a keratinocytákra és a sejtközötti kapcsolatokra - Az atopiás dermatitis kialakulásában játszott szerepük.

(88. évf. 2012/3. szám 72-76.)

\section{Legjobb kazuisztika}

Poór Adrienn dr., Hársing Judit dr., Hidvégi Bernadett dr.,

Holló Péter dr., Kárpáti Sarolta dr.:

Impetigo herpetiformis.

(88. évf. 2012/4. szám 117-120.)

\section{Legjobb kísérletes munka}

Csernus Adriána Evelin dr., Lengyel Zsuzsanna dr., Ferencz Judit dr., Battyáni István dr., Kálmán Endre dr., Battyáni Zita dr.:

Melanoma malignum in vivo mélységi terjedésének meghatározása nagyfelbontású ultrahanggal (18-, $22 \mathrm{Mhz})$.

(88. évf. 2012/1. szám 11-19.)

\section{Legjobb terápiás közlemény}

Bebes Attila dr., Nagy Tünde dr., Bata-Csörgő Zsuzsanna dr., Kemény Lajos dr., Dobozy Attila dr., Széll Márta dr.:

Az ABCG2 fehérje specifikus gátlásával növelhető a fotodinámiás terápia hatékonysága.

(88. évf. 2012/1. szám 5-10.) 